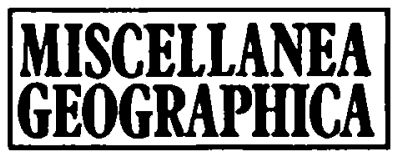

WARSZAWA 1996 VOL. 7

Hanna Cetnarska, Hanna Dziakowska

\title{
DIRECT INVESTMENT OF FOREIGN CAPITAL IN POLAND
}

As is well known, in the 90s Poland's transition to market economy and its integration with Western Europe began. Higher efficiency, greater ability to introduce innovations and more competitions in the economy are required to achieve these goals. This can occur through changes in the composition of output, type of ownership and size of enterprises. Shortage of investment resources, both in the public and private sectors, makes it necessary for Poland to rely on foreign capital investment, particularly on direct investment. This takes the form either of long-term greenfield investment or buyouts of either a part or all of the operating enterprises. Foreign investors can start business in Poland in the form of companies, limited either by shares or by guarantee, or in the form of branch permanent establishment.

In Poland foreign investment was started in 1976 and took the form of the firms run by foreign citizens of Polish origin. They began to grow in the eighties, particularly after the bill on the principles of running small business by foreigners on the territory of Poland had been passed. In 1983 there were almost 500 enterprises of this kind. They employed about 30 thousand people ( $0.2 \%$ of the total figure of employees in the economy) and turned out $0.25 \%$ of the total value of the country's output of goods and services. They were mainly small production units with employment up to 5 people, located mostly in big urban-industrial agglomerations of Warsaw, Poznań, and Cracow. $20 \%$ of all foreign firms were concentrated in the area of Warsaw. Most capital (about 25\%) came from Germany in that period.

An important growth in foreign investment occurred at the turn of the eighties. It was spurred by the bill on business activity with the participation of foreign economic subjects, passed on December 23rd, 1988, and then by the bill on the establishment of mixed capital enterprises, passed on 14th April, 1991. Since then joint venture companies could be established and more attractive conditions of operation were given to foreign capital.

In the years 1991-1994 the number of operating joint venture companies recorded five-fold, and their capital investment - over nine-fold. Small and medium-sized firms were still predominant; the firms employing more than 500 people constituted only $1.3 \%$ of the total number of these firms. 
Direct foreign investment in Poland (joint ventures)

\begin{tabular}{|l|r|r|r|}
\hline Basic data & \multicolumn{1}{|c|}{1991} & \multicolumn{1}{|c|}{1992} & \multicolumn{1}{c|}{1994} \\
\hline Number of recorded companies & $4,796.0$ & $10,131.0$ & $19,900.0$ \\
\hline Invested capital, (cumulatively in US\$ millions) & 471.0 & $1,409.0$ & $4,320.8$ \\
\hline $\begin{array}{l}\text { The average capital investment per company } \\
\text { (in US\$ thousands) }\end{array}$ & 98.2 & 139.1 & 217.1 \\
\hline Total employment in the companies: & & & \\
- in thou sands & 117.6 & 230.0 & 310.0 \\
- percentage of the country's total employment & 1.1 & 2.4 & 3.3 \\
\hline Average number of employees per company & 24.5 & 22.7 & 15.6 \\
\hline
\end{tabular}

Source: The State Agency for Foreign Capital Investment

Table 2

The largest foreign investors in Poland in 1995

\begin{tabular}{|l|c|c|l|l|}
\hline Investor & $\begin{array}{c}\text { Investment } \\
\text { made \$US } \\
\text { millions }\end{array}$ & $\begin{array}{c}\text { Investment } \\
\text { liabilities } \\
\$ U S \\
\text { millions }\end{array}$ & $\begin{array}{c}\text { Country of } \\
\text { origin }\end{array}$ & \multicolumn{1}{|c|}{$\begin{array}{c}\text { Branch of } \\
\text { business }\end{array}$} \\
\hline $\begin{array}{l}\text { International Paper } \\
\text { Company }\end{array}$ & 275 & 45 & USA & paper products \\
\hline Fiat & 260 & 1,581 & Italy & cars \\
\hline $\begin{array}{l}\text { Polish-American Enterprise } \\
\text { Fund }\end{array}$ & 250 & 36 & USA & various branches \\
\hline Coca-Cola & 235 & 50 & USA & soft drinks \\
\hline $\begin{array}{l}\text { European Bank for } \\
\text { Reconstruction \& } \\
\text { Development }\end{array}$ & 222 & 0 & multinational & various branches \\
\hline $\begin{array}{l}\text { International Finance } \\
\text { Corporation }\end{array}$ & 218 & 0 & multinational & various branches \\
\hline Piklington & 166 & 0 & Great Britain & glass production \\
\hline Asea Brown Bovery & 150 & 0 & multinational & $\begin{array}{l}\text { power } \\
\text { generation } \\
\text { equipment }\end{array}$ \\
\hline $\begin{array}{l}\text { Thomson Consumer } \\
\text { Electronics }\end{array}$ & 147 & 37 & France & $\begin{array}{l}\text { electric } \\
\text { equipment }\end{array}$ \\
\hline $\begin{array}{l}\text { ING Internationale } \\
\text { Nederlanden Bank }\end{array}$ & 140 & 0 & Holland & banking \\
\hline
\end{tabular}

Source: The State Agency for Foreign Capital Investment, 1995

The largest proportion of foreign investment was made in industry $(61 \%)$, mainly in the electrical equipment industry, food-processing industry, wood-based and paper industries; that was followed by the investment in telecommunication, financial and banking sectors, and the smallest proportion $(0.2 \%)$ was in agriculture. In the nineties geographical composition of the capital inflow to Poland changed. The capital investment came mainly from the United States, with Germany and Italy occupying the 


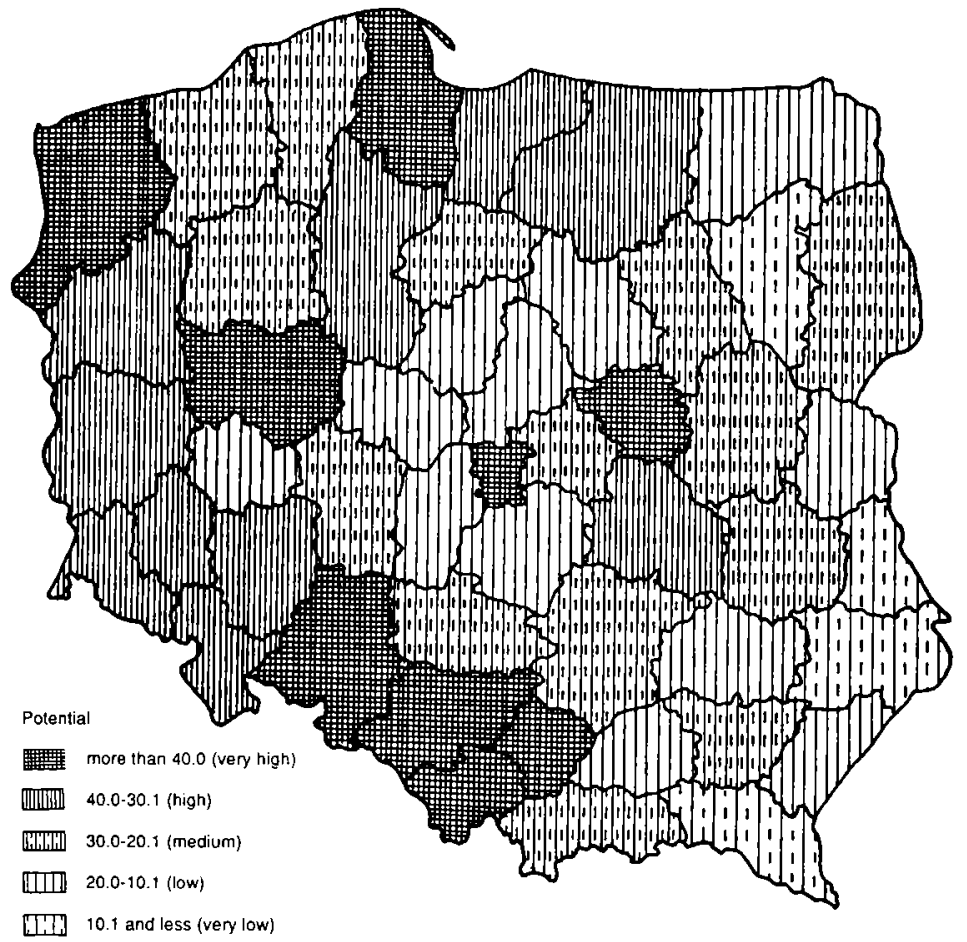

Fig. 1. Spatial differentiation of direct foreign investment potential

second and third places respectively. In 1994 the American investment in different branches of the Polish economy amounted to US $\$ 1.7$ billion. Multinational corporations, with their direct investment of \$US 861 million came in the second place, capital investment of Germany occupied the third place, and the one of Italy, amounting to \$US 378 million - the fourth.

In 1994 the sales of mixed-capital companies amounted to over \$US 15.2 billion, representing nearly $11 \%$ of the total sales in the economy.

To present spatial distribution of foreign investment in Poland and identify the areas where it is mostly concentrated foreign capital potential of each of 49 voivodeships was computed by ranking the 49 administrative units by their ratios in the three major indicators of foreign investment: the number of mixed-capital companies, - their total employment, - their declared capital.

By summing up the ranks voivodeships were put in a decreasing order showing the potential of direct investment made by foreign capital in each of them.

As it follows from the map, the largest potentials of foreign investment were identified in the three voivodeships of Central Poland: Warsaw, Lódź, Poznan and in two other areas - one of them being located in the south of 
the country, linked to the industrial centres of Silesia, and the other - in the north, near the sea with the largest seaports of Gdańsk and Szczecin.

In those regions (nine voivodeships) $68.9 \%$ of the total number of the companies, $61.2 \%$ of the employees and $69.7 \%$ of the total capital declared by foreign investors concentrated. The position of the Warsaw capital city voivodeship was particularly strong, its potential of foreign investment capital exceeding nearly fourfold the one of the remaining voivodeships.

Direct investment tends to be heavily concentrated in the large urbanindustrial agglomerations. They can be defined as the regions with favourable economic environment, their distinctive features being relatively modern industry with extensive market links, highly qualified staff and well developed research and development infrastructure. The above mentioned regions have also had an important private handicrafts sector. As a result, diversification of production structures and growth of private entrepreneurship, stimulated by market forces, could occur.

Continued concentration of foreign investment in the few regions of the country is not desirable thing, in view of development needs of the underprivileged regions. Among them there are the regions most seriously affected by the recession, including old industrial regions (e.g. the Sudety mountains) and the ones dominated by the state rural sector, currently subject to ownership transformation process (large parts of Northern Poland).

The smallest foreign investment potential is represented by the typically rural regions, with poorly developed infrastructure, with small or little differentiated industrial sector. These are the border-line voivodeships, located in the south-east - the voivodeships of Zamość, Chełm, Przemyśl, and Krosno (all of them were established as a result of the administration reform of 1975). Their local markets are narrow, they have high unemployment rates, and are situated far away from the main transportation routes.

From the point of view of the economic needs of Poland the size of foreign direct investment must be regarded as unadequate. It is also quite small in size as compared with foreign direct investment in other countries of Central and Eastern Europe. Thus, in 1994 the figure of foreign capital investment per l inhabitant amounted to \$US 105 i.e., was eight times less than in Hungary and near twice less than in the Czech Republic. Taking market size and growth dynamics of the economy Poland should certainly be an attractive place for foreign capital investment. 